УДК: 597.2/.5:574.34 (477.75)

\title{
ДИНАМИКА ФОНОВЫХ ВИДОВ РЫБ В АКВАТОРИИ КАРАДАГСКОГО ПРИРОДНОГО ЗАПОВЕДНИКА ПО ДАННЫМ ВИЗУАЛЬНЫХ УЧЁТОВ \\ В 2016-2018 гг. *
}

Мальцев В.И., Белецкая М.А.

ФГБУН «Карадагская научная станция им. Т.И.Вяземского - природный заповедник РАН», пгт. Курортное, г. Феодосия, Российская Федераиия,

e-mail: maltsev1356@gmail.com

Впродолжение 2016-2018 гг. в результате мониторинга рыб, выполненного методом визуального учёта, на трёх прибрежных биотопах акватории Карадагского природного заповедника было зарегистрировано 25 видов рыб, что составляет $50 \%$ от списочного видового состава прибрежного ихтиокомплекса заповедной акватории. 10 видов из упомянутых 25 с встречаемостью более 50\% можно отнести к фоновым для этой акватории, 8 из них являются резидентами, и только два вида - мигрантами. В 2017 г. наблюдалось снижение обилия рыб: среднесезонные показатели численности не превышали 3500 особей на 1 га, что в 3-6 раз меньше соответствующих показателей 2016 и 2018 годов. Согласно величине индекса поддерживающей способности все три биотопа в 2017 г. характеризуются средним уровнем поддерживающей способности $(\mathrm{A}=0,34-0,42)$, тогда как в 2016 и 2018 гг. - высоким $(\mathrm{A}=0,43-$ $0,62)$. Есть основания считать, что это нормальные межгодовые флуктуации.

Ключевые слова: Карадагский природный заповедник, заповедная акватория, прибрежный ихтиокомпдекс, визуальный учёт.

\section{Введение}

В результате создания заповедных объектов возникла необходимость ведения мониторинга биоразнообразия на подконтрольных территориях и акваториях, в том числе и их рыбного населения. Эта информация становится неотъемлемой частью Летописи природы.

За 100-летнюю историю существования научного и природоохранного учреждения на Карадаге рыбное население исследовалось многократно. Существует значительное количество публикаций, содержащих списки видов рыб, встреченных в акватории у Карадага, включая современную заповедную акваторию (рис.1), и в непосредственной близости от него (Виноградов, 1930, 1947, 1949, Прокудина, 1957, Смирнов, 1959, Салехова и др., 1987, Костенко и др., 2004 и др.). При этом количественным показателям состояния прибрежного ихтиокомплекса уделялось гораздо меньше внимания.

Целью данного исследования являлось обобщение и анализ результатов экологического мониторинга состояния прибрежного ихтикомплекса, в частности, фоновых видов рыб в акватории заповедника.

\section{Материалы и методы}

Визуальный учет осуществлялся способом «на задержке дыхания» (Гетьман, 2007, Мальцев и др., 2015). Учет проводился как в пределах трансект длиной 25-50 м и шириной 10 м, так и при «маршрутных» наблюдениях на отдельных участках. Прибрежный ихтиокомплекс Карадагского природного заповедника исследовался в июне-сентябре 2016-2018 годов.

\footnotetext{
* Работа выполнена в рамках темы гос. задания № АААА-А19-119012490045-0 «Изучение фундаментальных физических, физиолого-биохимических, репродуктивных, популяционных и поведенческих характеристик морских гидробионтов».
} 


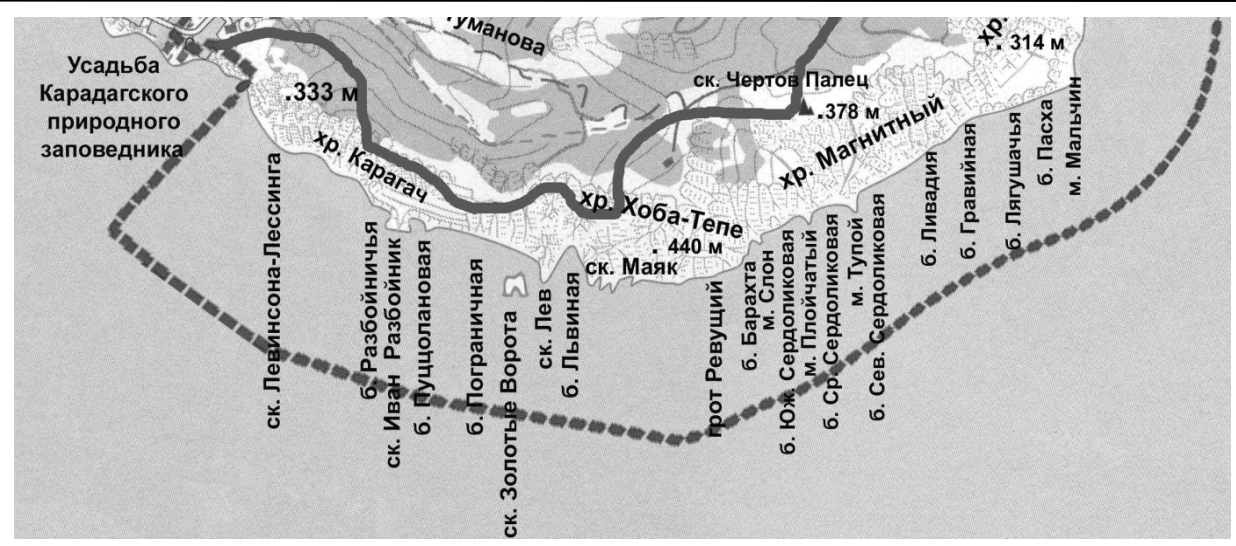

Рис. 1. Акватория Карадагского природного заповедника.

Заповедная акватория характеризуется наличием почти сплошного каменистоскалистого пояса, сложенного булыжно-галечными наносами (размер камней 10-300 см), образованными породами вулканического происхождения. Имеют место также большие глыбы и скалы, вертикально спускающиеся в море, большей частью заросшие макроводорослями с доминированием цистозиры. Песчаные донные отложения у побережья существуют только в виде небольших вкраплений среди нагромождений камней, а на отдалении 100-200 м становятся преобладающим типом субстрата.

Для оценки характера динамики фоновых видов рыб заповедной акватории были выбраны три биотопа:

1. мелководье у Кузьмичева Камня $\left(44^{\circ} 54.691 \mathrm{~N}, 035^{\circ} 12.757 \mathrm{E}\right)$,

2. мелководье с координатами $44^{\circ} 54.690 \mathrm{~N}, 035^{\circ} 12.662 \mathrm{E}$ (береговой ориентир дерево лох серебристый),

3. мелководье с координатами $44^{\circ} 54.705 \mathrm{~N}, 035^{\circ} 12.546 \mathrm{E}$ (береговой ориентир скала «Малый парус»).

\section{Результаты исследований}

В результате визуальных учетов в акватории Карадагского природного заповедника непосредственно идентифицировано 25 видов рыб (табл. 1), или 50\% от общего количества видов, встречающихся в заповедной акватории (Мальцев и др., 2017). 10 видов из упомянутых 25 с встречаемостью более 50\% можно отнести к фоновым для этой акватории: атерина, ласкирь, султанка, зеленушка-перепелка, губан глазчатый, зеленушка-рябчик, зеленушка-рулена, собачка морская сфинкс, собачка морская обыкновенная, бычок-рыжик.

Таблица 1.

Встречаемость видов рыб в исследуемых биотопах акватории Карадагского природного заповедника в 2016-2018 гг.

\begin{tabular}{|c|c|c|c|c|c|c|c|c|c|c|c|}
\hline \multirow{3}{*}{ Виды } & \multicolumn{3}{|c|}{2016 г. } & \multicolumn{3}{|c|}{2017 г. } & \multicolumn{3}{|c|}{2018 г. } & \multirow{3}{*}{$\begin{array}{l}\text { Экол. } \\
\text { особен- } \\
\text { ности }\end{array}$} & \multirow{3}{*}{$\begin{array}{l}\text { Оценки } \\
\text { встреча- } \\
\text { емости и } \\
\text { обилия }\end{array}$} \\
\hline & \multicolumn{3}{|c|}{ Биотопы } & \multicolumn{3}{|c|}{ Биотопы } & & एTO & & & \\
\hline & 1 & 2 & 3 & 1 & 2 & 3 & 1 & 2 & 3 & & \\
\hline $\begin{array}{l}\text { 1. Mugil cephalus - } \\
\text { лобан }\end{array}$ & & & & & & & & & & Мигр. & $\begin{array}{l}\text { Оч.редкий } \\
\text { Малочисл. }\end{array}$ \\
\hline 2. Liza aurata - сингиль & & & & & & & & & & Мигр. & $\begin{array}{l}\text { Оч.редкий. } \\
\text { Обыч. }\end{array}$ \\
\hline $\begin{array}{l}\text { 3. L. haematocephalus - } \\
\text { пиленгас }\end{array}$ & & & & & & & & & & Миг. & \begin{tabular}{|l|} 
Оч.ред. \\
Малочисл.
\end{tabular} \\
\hline $\begin{array}{l}\text { 4. Atherina boyeri- } \\
\text { атерина }\end{array}$ & & & & & & & & & & Мигр. & $\begin{array}{l}\text { Част. } \\
\text { Многочисл. }\end{array}$ \\
\hline
\end{tabular}




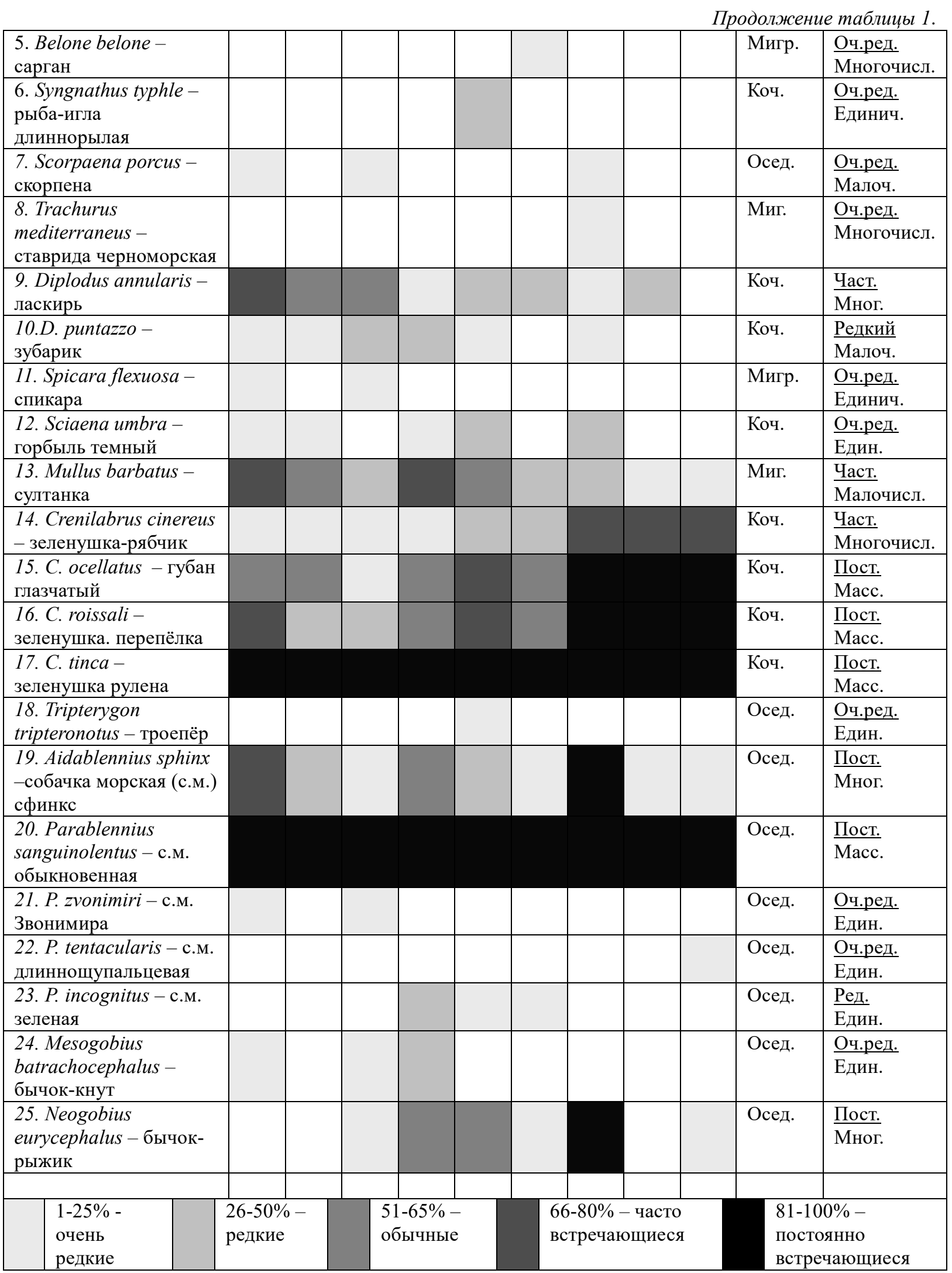

Примечания: Мигр. - мигрирующий вид, Коч. - кочевник, Осед. - оседлый вид, Оч.редкий - очень редко встречающийся в биотопе вид, Редкий -редко встречающийся в биотопе вид, Част. - часто встречающийся в биотопе вид, Пост. - постоянно встречающийся в биотопе вид, Единич. - отмечены единичные экземпляры, Малочисл. - малочисленный вид, Многочисл. - многочисленный вид, Масс. массовый вид 
Из этих 10 видов 8 относятся к экологическим группам «оседлые» и «кочевники», которые В.В. Шагановым (2018) отнесены к «резидентам»; мигрантами являются только два вида из приведенного «караткого списка».

Впродолжение летнего сезона 2016 и 2018 наблюдается увеличение показателя обилия рыб прибрежного ихтиокомплекса с 2-3 тысяч до 23 тысяч особей на 1 га (рис. 2, 3). Это увеличение в значительной степени обусловнено появлением в июлесентябре массы сеголетней молоди преимущественно кефалеобразных.

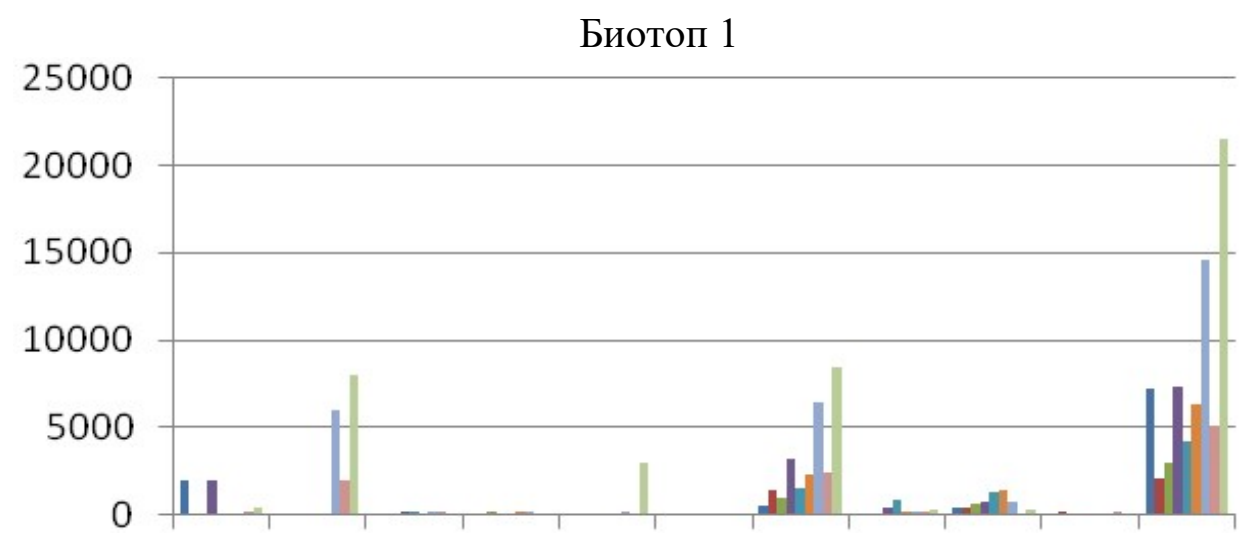

Биотоп 2

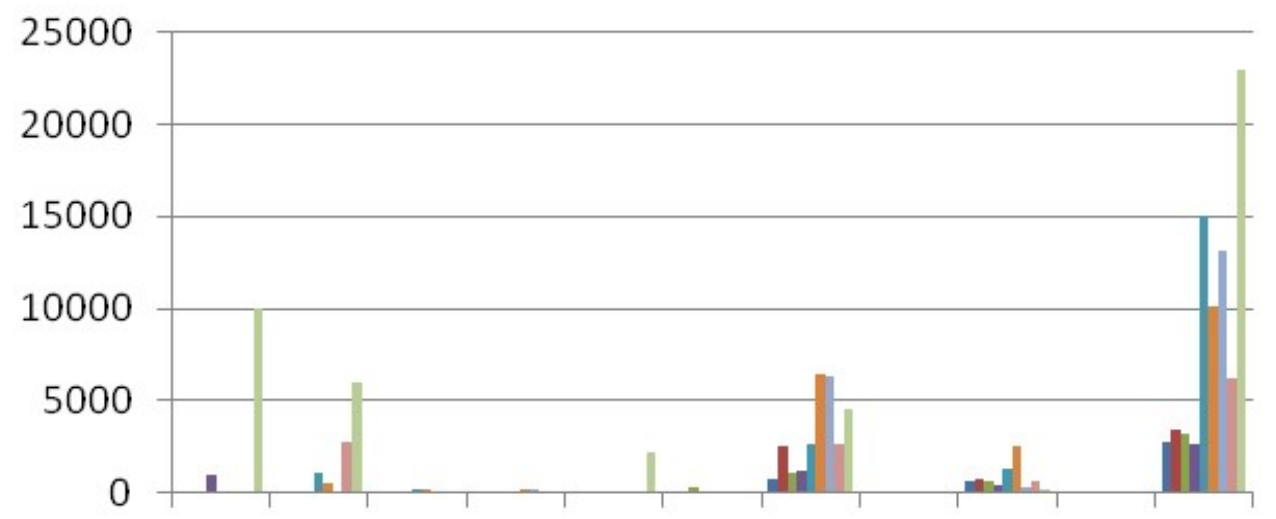

22 июня

28 июня

4 июля

27 июля

3 авг.

11 авг.

$26 \mathrm{aвr}$.

Биотоп 3

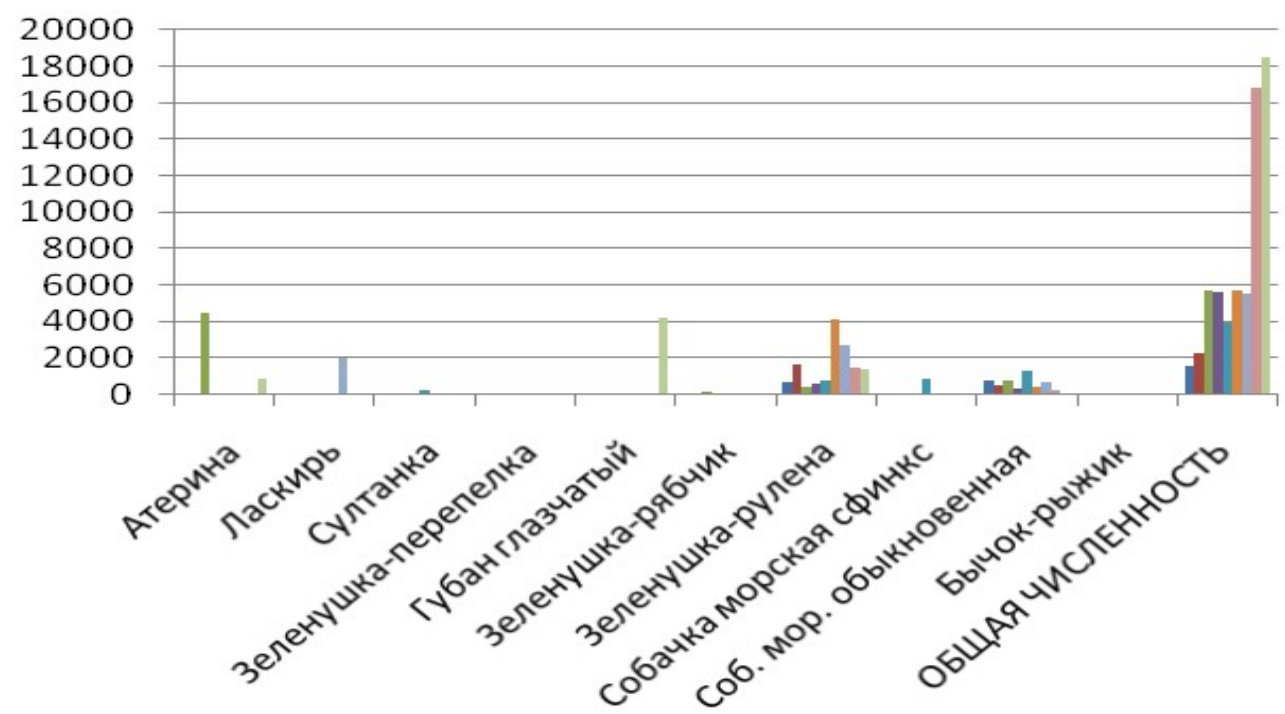

6 сент.

16 сент.

Рис. 2. Динамика численности (экз./га) фоновых видов прибрежного ихтиокомплекса в акватории Карадагского природного заповедника в 2016 г. 
На фоне сходной динамики прибрежного ихтиокомплекса в 2016 и 2018 гг. имеет место существенное отклонение показателей обилия рыб в исследованных биотопах в 2017 г. (рис. 4). Так, в 2017 г. наблюдалось снижение обилия рыб: среднесезонные показатели численности не превышали 3500 особей на 1 га, что в 3-6 раз меньше соответствующих показателей 2016 и 2018 годов.

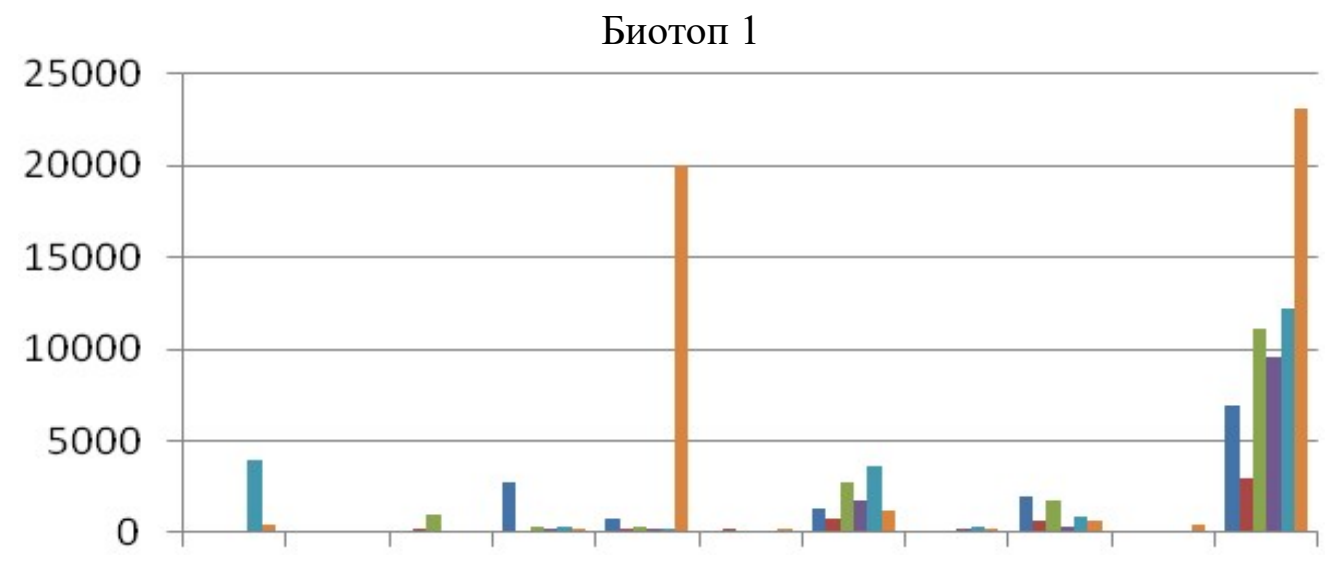

Биотоп 2

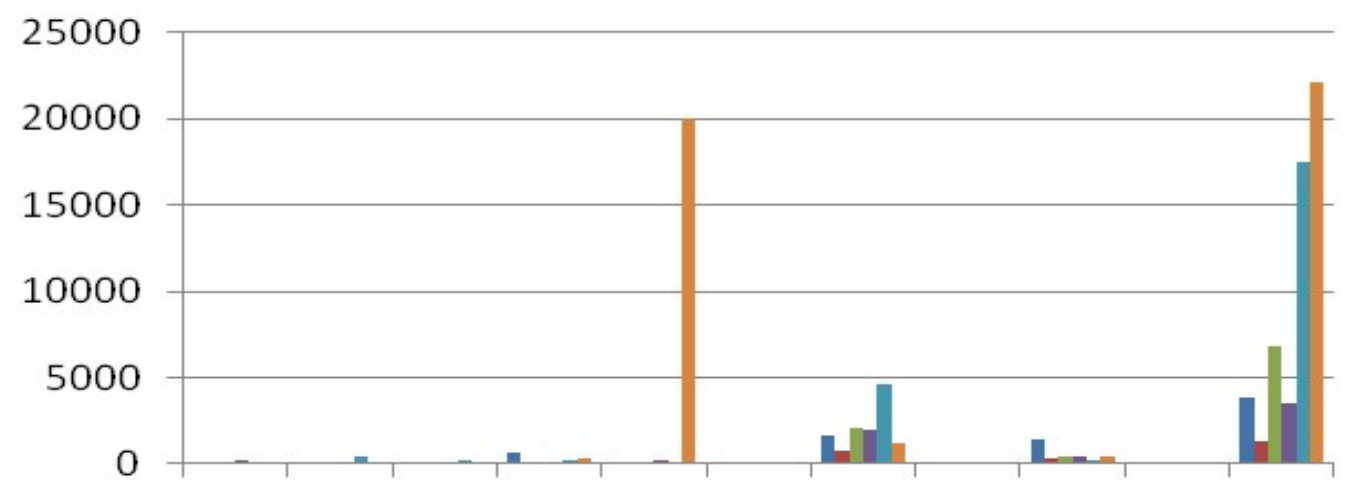

Биотоп 3

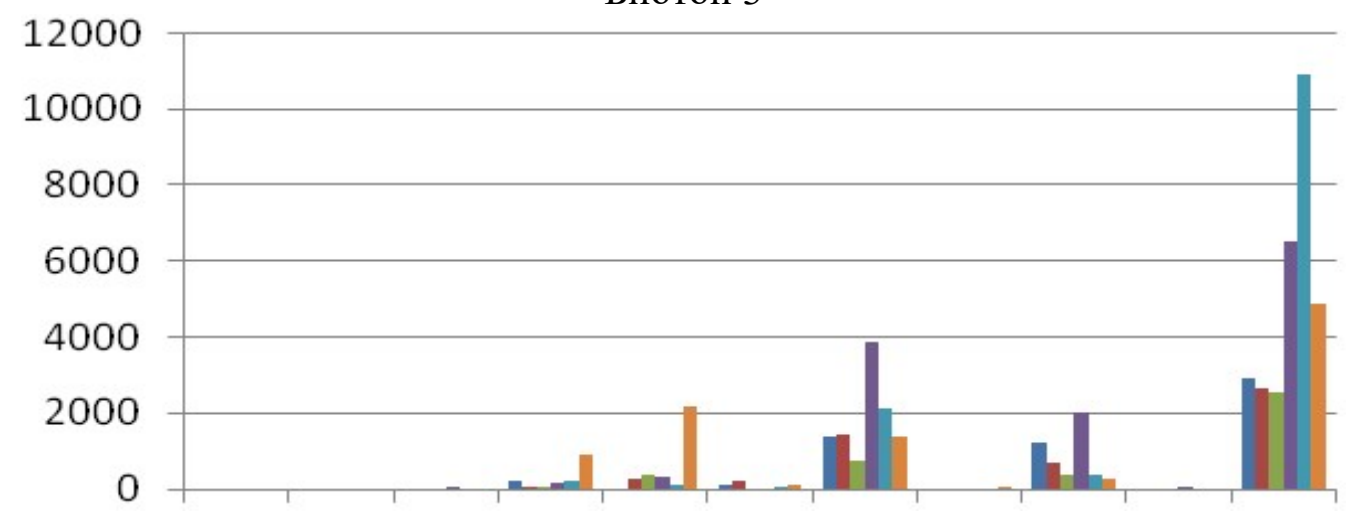

20 июня

27 июля

8 авг.

15 авг.

29 авг.

24 сент.

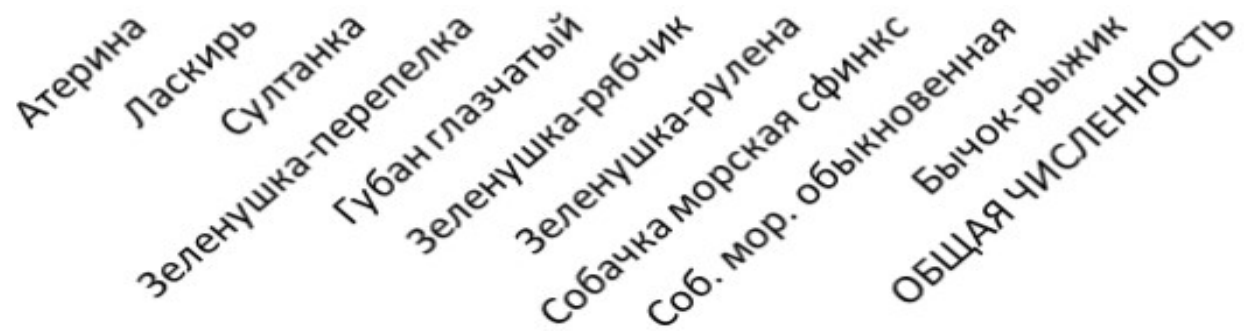

Рис. 3. Динамика численности (экз./га) фоновых видов прибрежного ихтиокомплекса в акватории Карадагского природного заповедника в 2018 г. 
По рассчитанному индексу поддерживающей способности (Maltsev et al., 2018) все три биотопа (рис. 5) в 2017 г. характеризуются средним уровнем поддерживающей способности $(\mathrm{A}=0,34-0,42$, III класс), тогда как в 2016 и 2018 гг. - высоким $(\mathrm{A}=0,43-$ 0,62, II класс).

Биотоп 1

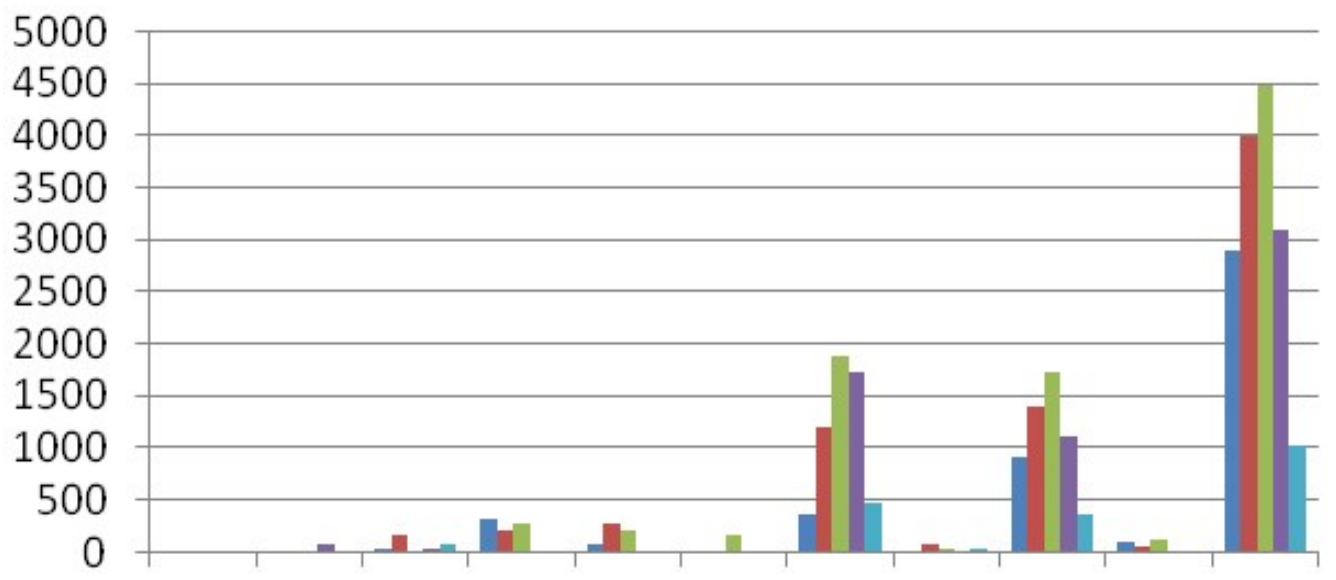

Биотоп 2

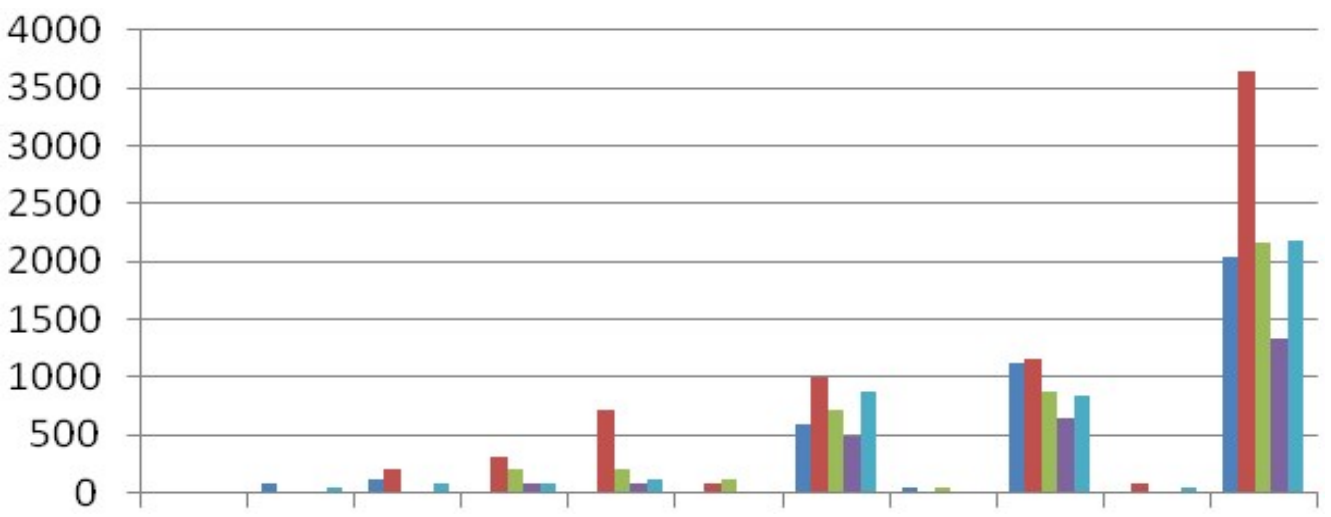

Биотоп 3
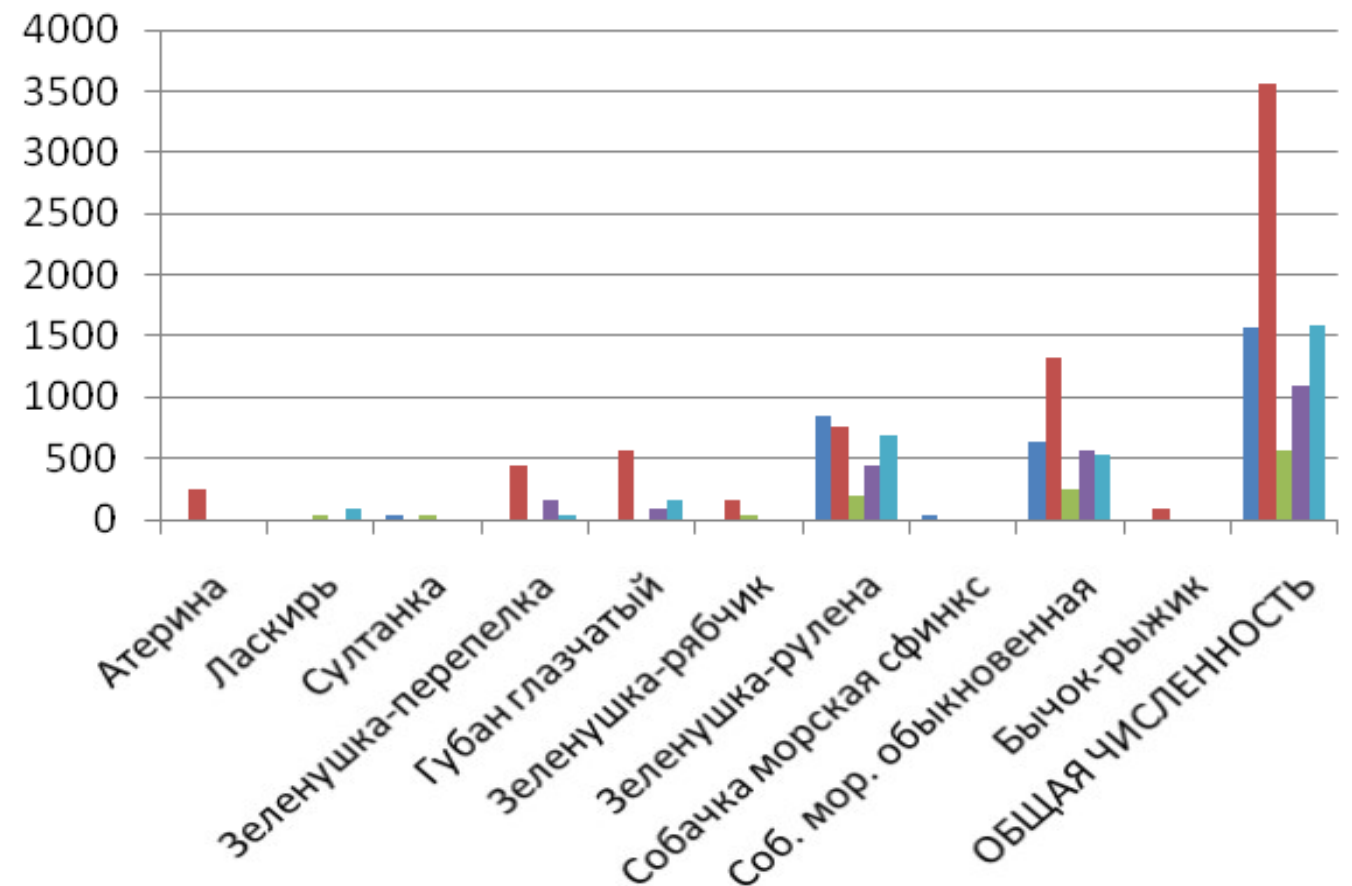

24 июля

1 авг.

9 авг.

24 авг.

28 авг.

Рис. 4. Динамика численности (экз./га) фоновых видов прибрежного ихтиокомплекса в акватории Карадагского природного заповедника в 2017 г. 

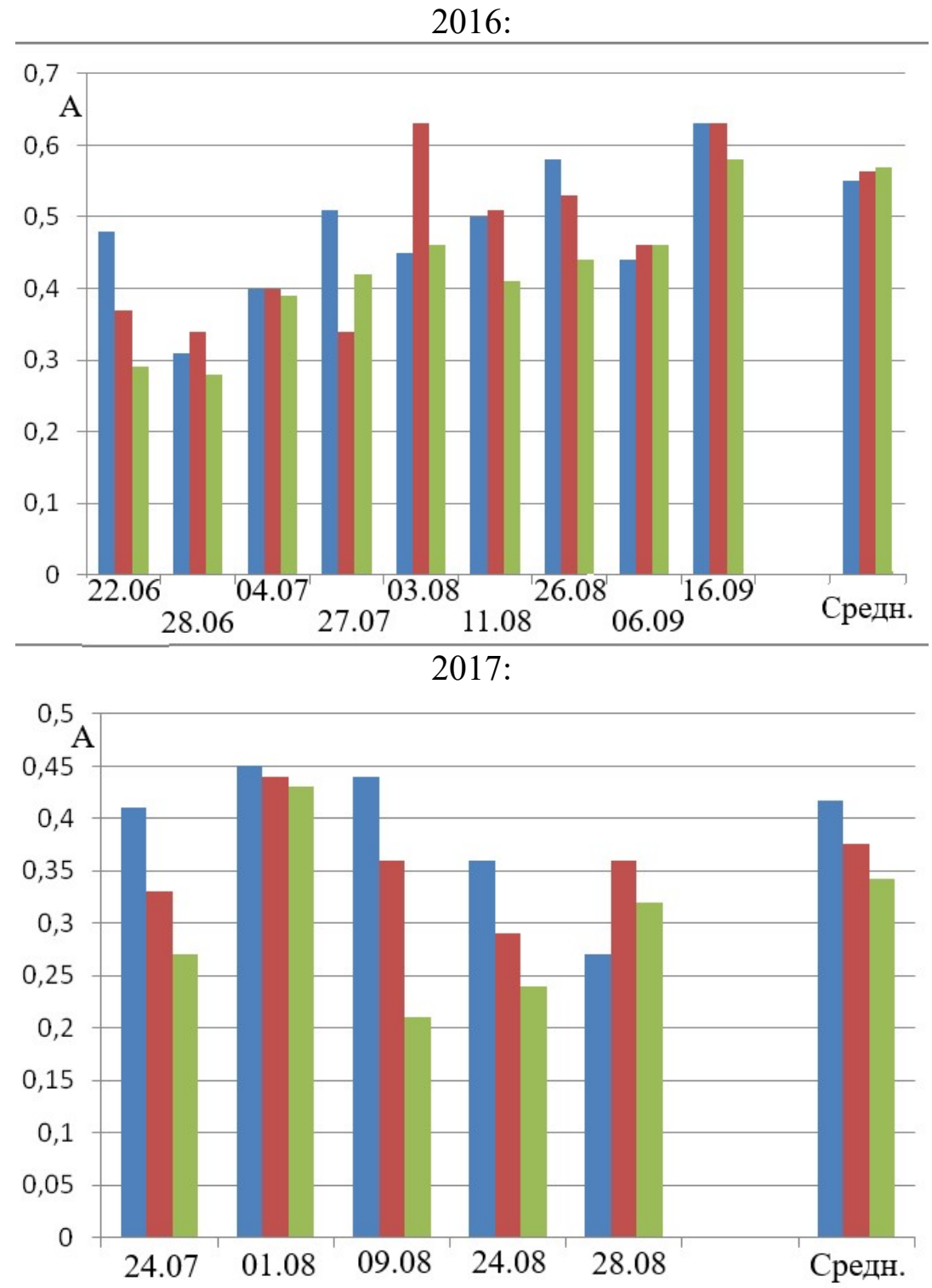

2018:

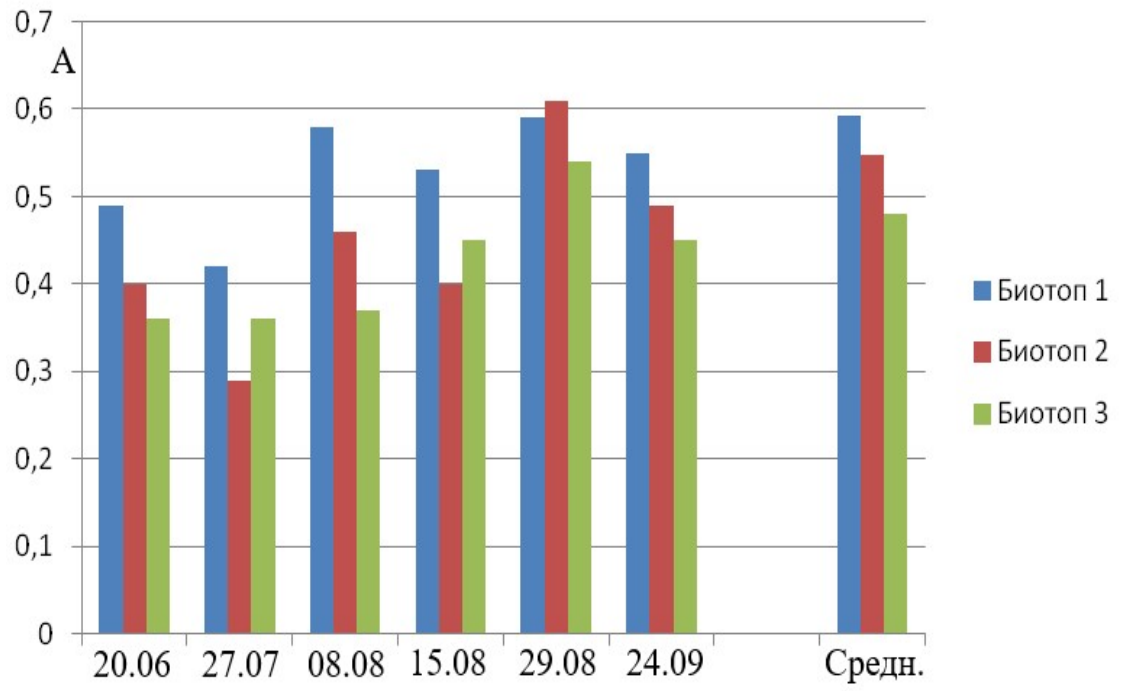

Рис. 5. Динамика значений индекса поддерживающей способности относительно прибрежного ихтиокомплекса исследованных биотопов в акватории Карадагского природного заповедника в 2016-2018 гг. 
Причины таких различий трудно объяснить на основании только имеющихся на сегодняшний день данных. Есть основания считать, что это нормальные межгодовые флуктуации, поэтому важно продолжать и углублять исследования динамики рыбного населения как заповедной акватории, так и сопредельных, с целью выявления многолетних закономерностей динамики прибрежного ихтиокомплекса заповедной акватории.

Анализ количества случаев «попадания» биотопов на соответствующее место (от первого до третьего) по величине индекса поддерживающей способности показывает, что наиболее значимым с точки зрения био(ихтио)разнообразия является биотоп 1; это подтверждается также наибольшим видовым обилием: 21 встреченный здесь вид против 17-ти для биотопа 2 и 19-ти для биотопа 1 (табл. 2).

Таблица 2.

Количество случаев «попадания» биотопов на соответствующее место (от первого до третьего) по величине индекса поддерживающей способности по данным визуальных учётов 2016-2018 гг.

\begin{tabular}{|c|c|c|c|}
\hline \multirow{2}{*}{ Место } & \multicolumn{3}{|c|}{ Биотопы } \\
\cline { 2 - 4 } & 1 & 2 & 3 \\
\hline 1 & $\mathbf{1 3}$ & 7 & 0 \\
\hline 2 & 4 & $\mathbf{1 0}$ & 6 \\
\hline 3 & 3 & 3 & $\mathbf{1 4}$ \\
\hline
\end{tabular}

В целом на сегодняшний день есть основания считать, что заповедник в основном обеспечивает нормальное существование прибрежного ихтиокомплекса в заповедной акватории. Снижение строгости заповедного режима, имеющее место в последние годы и приводящее к многочисленным несанкционированным вторжениям посторонних в заповедную акваторию, пока еще не стало критичным для прибрежного ихтиокомплекса, однако, скорейшее восстановление заповедного режима на должном уровне является необходимым и актуальным.

\section{Выводы}

1. В результате визуальных учетов в 2012-2018 гг. в акватории Карадагского природного заповедника непосредственно идентифицировано 25 видов, или 50\% от общего количества видов, встречающихся в заповедной акватории.

2. Основу прибрежного ихтиокомплекса (встречаемость более 50\%) составляют следующие виды: атерина, ласкирь, султанка, зеленушка-перепелка, губан глазчатый, зеленушка-рябчик, зеленушка-рулена, собачка морская сфинкс, собачка морская обыкновенная, бычок-рыжик. Из этих 10 фоновых видов 8 относятся к экологическим группам «оседлые» и «кочевники», составляющим более крупную группу «резидентов»; мигрантами являются только два вида из упомянутого «караткого списка».

3. Показатели обилия фоновых видов рыб в акватории заповедника в 2016 и 2018 годах выше таковых в 2017 г. приблизительно в 3 раза. По рассчитанному индексу поддерживающей способности в 2017 г. все три биотопа, на которых проводился мониторинг способом визуального учета, характеризуются средним уровнем поддерживающей способности ( $\mathrm{A}=0,34-0,42$, III класс), тогда как в 2016 и 2018 гг. высоким (A=0,43-0,62, II класс). По величине индекса поддерживающей способности наиболее значимым с точки зрения био(ихтио)разнообразия является биотоп 1 (координаты $44^{\circ} 54.691 \mathrm{~N}, 035^{\circ} 12.757 \mathrm{E}$ ), что подтверждается также наибольшим в нём видовым обилием. 
4. В целом на сегодняшний день есть основания считать, что заповедник в основном обеспечивает нормальное существование прибрежного ихтиокомплекса в заповедной акватории. Снижение строгости заповедного режима, имеющее место в последние годы, пока еще не стало критичным для этой части биоты.

\section{Список литературы}

1. Виноградов К.A. Материалы по ихтиофауне района Карадагской биологической станции (Черное море) // Труды Карадагской биологической станции. - 1930. - Вып. 3. - C. 137-143.

2. Виноградов К.О. Список риб Чорного моря, що зустрічаються в районі Карадагської біологічної станції // Доповіді Академії наук УРСР. Відділ біол. Наук. - 1947. - № 5. - C. 57-61.

3. Виноградов К.A. Список рыб Черного моря, встречающихся в районе Карадагской биологической станции, с замечаниями об их биологии и экологии // Труды Карадагской биологической станции. - 1949. - Вып. 7. - С. 76-106.

4. Гетьман Т.П. Визуальные подводные наблюдения при оценке качественноколичественных показателей ихтиоцена // Экология моря. - 2007. - Вып. 74. - С. 13-17.

5. Костенко Н.С., Шаганов В.В. Рыбы // Карадаг. Гидробиологические исследования. Сборник научных трудов, посвящённый 90-летию Карадагской научной станции им. Т.И. Вяземского и 25-летию Карадагского природного заповедника НАН Украины. Книга 2-я. - Симферополь: СОНАТ, 2004. - С. 440-453.

6. Мальчев В.И., Иванчикова Ю.Ф. Прибрежный ихтиокомплекс акватории Карадагского природного заповедника (Черное море, Крым) // 100 лет Карадагской научной станции им. Т.И. Вяземского: сборник научных трудов. - Симферополь: Н. Оріанда, 2015. - С. 584-589.

7. Мальиев В.И., Шаганов В.В., Василеи В.Е. Современное состояние ихтиокомплекса Карадагского природного заповедника // Труды Карадагской научной станции им. Т.И. Вяземского - природного заповедника РАН. - 2017. - Выпуск 4 (2). - С. 36-54.

8. Прокудина Л.А. Каталог фауны и флоры Чёрного моря района Карадагской биологической станции // Труды Карадагской биологической станции. - 1952. Вып. 12. - С. 116-127.

9. Салехова Л.П., Костенко Н.С., Богачик Т.А., Минибаева О.Н. Состав ихтиофауны в районе Карадагского заповедника (Черное море) // Вопросы ихтиологии. - 1987. Т. 27, Вып. 6. - С. 898-905.

10. Смирнов А.Н. Материалы по биологии рыб Черного моря в районе Карадага // Труды Карадагской биологической станции. - 1959. - Вып. 15. - С. 31-109.

11. Шаганов В.В. Рыбы // Биология Чёрного моря у берегов Юго-Восточного Крыма / под ред. Н.С. Костенко. - Симферополь: ИТ «АРИАЛ», 2018. - С. 130-143.

12. Maltsev V.I., Beletskaya M.A. Habitat carrying capacity index: a formalized assessment of habitat importance to maintain diversity of the littoral fish assemblage // Ukrainian Journal of Ecology. - 2018. - № 8 (1). - P. 680-687. - DOI: 10.15421/2018_266. 


\title{
DYNAMICS OF THE MOST COMMON FISH SPECIES AT THE AQUATORY OF THE KARADAG NATURE RESERVE ACCORDING TO VISUAL REGISTRATION IN 2016-2018
}

Maltsev V.I., Beletskaya M.A.

\author{
T.I. Vyazemsky Karadag Scientific Station - Nature Reserve of the RAS, \\ Kyrortnoe, Feodosia, Russian Federation \\ e-mail: maltsev1356@gmail.com
}

During 2016-2018 25 fish species representing 50\% of the species are listed for coastal fish assemblage of protected area of the Karadag Nature Reserve were registered for three shallow water habitats as a result of monitoring of fish provided by visual registration. 10 species of that 25 with an occurrence over $50 \%$ can be attributed to the most common for this area; 8 of them are residents, and only two species are migrants. In 2017 there was a decrease in the abundance of fish: the average seasonal number did not exceed 3500 individuals per 1 hectare which is 3-6 times less than the corresponding numbers in 2016 and 2018. According to the value of the habitat caring capacity index all the three habitats in 2017 are characterized by an average level of caring capacity $(\mathrm{A}=0.34-0.42)$, while in 2016 and 2018 - by high level $(\mathrm{a}=0.43-0.62)$. It seems as normal interannual fluctuations.

Keywords: Karadag Nature Reserve, protected aquatory, littoral fish assemblage, visual registration.

Поступила в редаки̧ию 05.05.2019 г. 